\title{
Immune Response Profile in Susceptibility and Protection in Visceral Leishmaniasis
}

\section{Jacqueline A Fiuza and Soraya T Gaze}

Cellular and Molecular Immunology Group, Rene Rachou Institute, Oswaldo Cruz Foundation, Brazil

*Corresponding author: Soraya T Gaze, Cellular and Molecular Immunology Group, Rene Rachou Institute, Oswaldo Cruz Foundation, Brazil, E-mail: soraya.gaze@minas.fiocruz.br

Received date: July 04, 2018; Accepted date: August 15, 2018; Published date: August 20, 2018

Copyright: $\bigcirc 2018$ Fiuza JA, et al. This is an open-access article distributed under the terms of the Creative Commons Attribution License, which permits unrestricted use, distribution, and reproduction in any medium, provided the original author and source are credited.

\begin{abstract}
Among the clinical forms of leishmaniasis, visceral leishmaniasis is the most debilitating clinical form because it compromises mainly liver and spleen in the host. The immune response against the parasite and immune factors relating to protection or susceptibility are not well established. Experimental models and natural infection in dogs also have different patterns to human disease. In the scientific community, many groups are developing different strategies to find an effective vaccine that could be used in dogs, and/or human in the future, with success. The vaccine to leishmaniasis, together with other sanitary strategies, could decrease the infection rates in endemic countries. Here, it is presented a review of the last studies focusing in a vaccine against visceral leishmaniasis.
\end{abstract}

Keywords: Leishmaniasis; Fever; Hematemesis

\section{Introduction}

Visceral leishmaniasis (VL), caused by the parasites Leishmania donovani and $L$. infantum, is endemic in 65 countries. The disease affects more than 200,000 people per year, with high case-fatality rates if not treated [1].

Human VL is characterized by long-term irregular fever, splenomegaly, hepatomegaly, lymphadenopathy, anemia, leukopenia, edema, epistaxis, hypergammaglobulinemia, hematemesis, weight loss and progressive weakness [2]. VL is considered to be the second most frequent cause of mortality and the fourth most frequent cause of morbidity in tropical diseases, with 20,000 to 40,000 deaths per year [1] and over 2 million years of Disability-Adjusted Life Years (DALYs) [3]. In addition, it is speculated that epidemiological data are underestimated, since clinical manifestation does not necessarily represent the absolute number of occurrences. For example, for each symptomatic case detected, there is estimation that there are, at least 6 to 20 asymptomatic infections [4]. In addition, the infection with Leishmania has gained attention as an opportunistic pathogen in HIV positive and other immunocompromised patients [5].

Among the factors that lead to the search for new alternatives to control VL are the development of resistant strains of the standard drug [6,7], toxicity of treatment and its inefficiency in patients coinfected with HIV virus $[6,8]$ to the increased incidence in immunocompromised patients and the difficulties in control based on the elimination of seropositive dogs [9]. The gold standard would be a highly efficient vaccine against the parasite. However, no human vaccine is available at the moment. For veterinary use, there are three commercially available. One in Brazil based on recombinant A2 protein plus saponin-(Leishtec) [10]. The second licensed in Europe, composed of purified excreted-secreted proteins of Leishmania infantum (LiESP), using a highly purified fraction of the Quillaja saponaria saponin as adjuvant (Canileish) [11]. The third, also licensed in Europe, is composed of 4 proteins (3 ribossomal and 1 hypothetical), using no adjuvants (Letifend) [12].

The host immune response has an important role in protection/ susceptibility in the course of Leishmania infection, besides the persistence and multiplication of the parasite. In the other hand, parasite exhibits different strategies to manipulate cell death and immune system to survive to establish infection [13]. The understanding of the mechanisms associated with immune evasion and disease progression is essential for the development of novel therapies and vaccine approaches. Here, we revise the immune response profile in natural and experimental infection by Leishmania infantum/Leishmania donovani, also after different vaccination approaches.

\section{Immune Response in Experimental Infection}

The events that occur after the inoculation of Leishmania sp. are essential to the course of the infection, and the involvement of the immune system is present by the complement system, polymorphonuclear neutrophils, natural killer cells (NK), macrophages, growth factors such as colony stimulating factor (GMCSF) and (TGF- $\beta$ ), and $[14,15]$. In general, these elements are activated in an attempt to contain the infection, either by enhancing the innate immune response by chemotaxis of more cells, or by the activation of the adaptive immune response. Because it is an intracellular parasite, the adequate immune response to Leishmania involves the activation of the microbicidal mechanisms of infected cells, especially macrophages, resulting mainly in the production of molecules such as reactive oxygen (ROI) and nitrogen intermediates (RNI) [16,17] .

Among the mechanisms involved in mammalian host protection against Leishmania infection, the development of Th1 immunity is crucial because triggers enhanced leishmanicidal activity by infected macrophages. In general, as demonstrated in murine model, protection against infection is attributed to the development of the cellular immune response triggered by $\mathrm{CD} 4^{+} \mathrm{Th} 1 \mathrm{~T}$ cells, characterized by the production of IL-12 and IFN- $\gamma$, which mediate the activation of 
macrophages, and nitric oxide production and consequently elimination of the parasite [18-23].

Immunopathogenesis of VL has been extensively studied in murine models of systemic infection. Genetically susceptible animals, such as $\mathrm{BALB} / \mathrm{c}$ and $\mathrm{C} 57 \mathrm{BL} / 6$ mice, infected with L. donovani or L. infantum, intravenously or intraperitoneally, present visceral parasitism. In the liver, amastigotes multiply rapidly during the first four weeks, but are soon controlled by the formation of inflammatory granulomas. Infected Kupffer cells produce chemokines (CCL2, CCL3, CCL19, CCL21 and CXCL10) capable of recruiting neutrophils, monocytes and $\mathrm{T}$ cells that are indispensable in the formation of the granuloma. Neutrophils, in addition to eliminating the parasite, induce the polarization of the immune response to the Th1 pattern. $\mathrm{CD}^{+} \mathrm{T}$ lymphocytes start to produce IL-12, which enhances the inflammatory response in granuloma among with production of IFN- $\gamma$, TNF- $\alpha$ and lymphotoxin a (LTa). These cytokines, in addition to increasing the recruitment of cells to structure the granuloma, activate the leishmanicidal mechanisms of infected cells producing reactive oxygen and nitrogen species and, in approximately eight weeks, liver infection is controlled [24,25].

In the spleen, multiplication of the parasite is late, but persistent compared to liver. Initially, IL-12 production is observed by dendritic cells migrating from the marginal zone to the periarteriolar zone in order to activate effector lymphocytes. However, this mechanism does not seem to be efficient in infection control, since the infection persists after several weeks and an enlargement of the spleen and changes in the splenic tissue are observed. This remodeling of the spleen is accompanied by an increase in the production of TNF- $\alpha$ which intensifies the depletion of macrophages and cells of the perateriolar zone, responsible for the release of CCL19 and CCL21, important in the migration of dendritic cells to the activation zone of effector $\mathrm{T}$ lymphocytes. In these models, IL-10 appears to be directly involved in parasite multiplication, since mice deficient in IL-10 production have infection controlled. It is suggested that IL-10 alters the expression of PD-1 (programmed death) and its ligand (PD-L1), inhibiting cytokine production and T-cell proliferation. IL-10 production can be induced by IL-27 and IL- 21 via activation of Tr1 cells [24,25]. It was observed that mice deficient for the IL-27 receptor are resistant against infection by L. donovani, but develop severe liver lesions [26].

In different models, some studies have shown the hostile effect of the leishmaniasis, induced by B cells [27-30]. In experimental VL, disease exacerbation is contributed by B cells. Smelt and collaborators (2000) demonstrated that B cell-deficient mice are highly resistant to $L$. donovani infection. However, B cells contribution to infection is not well known. But it seems that Leishmania infection could induce a production of short-lived Leishmania-specific IgG, and it decreases during chronic phase, suggesting that most antibodies produced are not specific for the parasite [31].

\section{Immune Response in Infected Patients}

Although endemic, less than $10 \%$ of the individuals infected by $L$. donovani or $L$. infantum present the classic form of VL. The majority of people who become infected with visceralizing Leishmania spp. never develop disease. The two groups (asymptomatic and symptomatic) are targets of studies in an attempt to understand the immunological dynamics of the disease. Looking only at serological parameters, it has been observed the presence of several mediators of the immune response during the active form of the disease, the cytokine storm. Several studies report high serum levels of cytokines type 1 (IFN- $\gamma$ and IL-12), type 2 (IL-4 and IL-13), Treg (IL-10 and IL-6), Th17 and TNF- $\alpha$ when compared with asymptomatic individuals [32-34]. After treatment, these levels of cytokines are similar to those of asymptomatic and healthy individuals. The clinical presentation of VL seems to be a consequence of the interaction parasite and the immune response developed by the host [35]. Thus, the outcome of infection would depend on the parasite's ability to evade non-specific defences of the host, to be recognized and phagocytosed, and survive within the phagocytes vacuole of macrophages [36]. During parasite-host interaction, complex signaling pathways are triggered by recognition of key parasite molecules [37]. Differences in virulence factors between species are responsible for the different clinical forms observed in leishmaniasis [38]. Protective immunity in leishmaniasis is mediated by the cellular immune response while the active disease is associated with a strong humoral response with absence of cellular response [38]. The control of infection is complex and the parasite is able to evade pro-oxidative responses and other macrophage effector mechanisms preventing the activation of a response [37,39].

Thus, the T cells and their producing cytokines play a central role in the immune response [40]. Parasitic macrophages, lymphocytes, dendritic cells and natural killers produce cytokines that are involved in both innate and adaptive responses to the parasite [22,41]. CD4 ${ }^{+}$ and $\mathrm{CD}^{+} \mathrm{T}$ cells are important to restrain visceral disease and are involved with the production of IL-2, IFN- $\gamma$ and IL-12 [42].

In contrast, if intense proliferation of B lymphocytes and the production of antibodies are abundant, the immune response is deleterious and non-protective for VL [43]. Therefore, the cellular immune response mediated by Th2 cells is associated with susceptibility, resulting in parasite persistence and infection progression (Kedzierski et al.). In VL, there is evidence of the predominance of Th2 cellular immune response during acute disease, leading to suppression of cellular reactivity against parasite antigens, absence of IL- 2 and IFN- $\gamma$, predominance of IL- 4 cytokine production and to polyclonal activation of $B$ cells resulting in hypergammaglobulinemia [44-47]. Unlike the polarization observed in murine models, a distinct Th1 and Th2 response pattern is not detected in human VL; In this case, the mixed Th1/Th2 immune response is observed during the course of infection, indicated by the high simultaneous levels of IFN- $\gamma$ and IL-10 in patients with the disease $[48,49]$. In VL, there is still no clear association between IL-4 production and active disease [50], but a direct correlation between IL-10 levels and disease progression has been described [46,51-56].

The cytokine IL-10 is indicated as the key factor of immunosuppression in VL. This fact is based on studies using murine model mainly, IL-10-deficient BALB/c and C57BL6 mice are highly resistant to $L$. donovani infection [53,57]. IL-10 has the ability to deactivate the leishmanicidal mechanisms of the macrophage and to down regulate the expression of $\mathrm{MHC}$ and co-stimulatory molecules $[54,58,59]$. It also decreases the production of IFN- $\gamma$ by $\mathrm{T}$ cells and inhibits DC migration to T cell areas [60-63]. Therefore, the evolution of the disease may be induced by IL-10 and it can condition host macrophages to increase parasite survival and replication, since this cytokine renders macrophages non-responsive to activation signals and inhibits the killing of parasites, by down regulating the production of nitric oxide and TNF- $\alpha$ [54,64-66]. However, there are some evidence suggesting that IL-10 may be host protective; particularly, in regulating a detrimental inflammatory response in the liver. Indeed, 
the extensive hepatic necrosis accompanying $L$. donovani infection in TNF-deficient mice may result from a concomitant defect in IL-10 induction [26,67]. Likewise, the severe hepatic pathology that follows $L$. donovani infection in IL27 $\mathrm{R}^{-/^{-}}$mice involves $\mathrm{CD} 4^{+} \mathrm{T}$ cells and may result from reduced IL-10 induction $[26,68]$.

Studies in patients confirm the efficacy of IFN- $\gamma$ and IL-12 mediated Th1 immune response to the elimination of Leishmania, to the detriment of Th2 IL-4 and IL-13 mediated immune response [41,45,69-71] . In classical VL, an absence of IFN- $\gamma$ and IL-2 production in response to soluble Leishmania antigens is observed in vitro [72]. This suppression is restored when anti-IL-10 is added, suggesting the negative modulatory role of this cytokine [73]. Indeed, individuals with the active form of VL have elevated serum levels of various cytokines, called "cytokine storm", including IFN- $\gamma$ and IL-10 [32,34,49,71,74-79]. Over time, other cytokines have been shown to regulate the immune response, as IL-6, IL-21 and IL-27 [74,80,81]. However, several aspects of this immune response in VL are still unclear.

The factors that influence susceptibility to VL remain an area of intense interest but are still largely a matter of speculation. As mentioned, many of the cytokines measured at elevated levels in VL patients indicate that the immune system responds appropriately but that other factors render these responses inadequate to contain the infection effectively. In addition, VL mostly affects populations in poor countries, where malnutrition or/and co-infection with helminthes or other organisms might be common, especially in rural area. It is demonstrated that low nutritional status can impair both innate and adaptive immune response [82,83]. In addition, co-infection with helminthes alters the Th1/Th2 balance, supporting Leishmania infection $[84,85]$. Also, it is demonstrated that testosterone induces parasite replication, resulting in more infected men with VL than women. This could suggest that hormone could induce or interfere in the susceptibility in this gender [54,86-88].

\section{Immune Response in Infected Dogs}

In Canine visceral leishmaniasis (CVL), cell-mediated immunity is able to control infection, and correlates with the absence of symptomatology [89-91], while the lack of this response has been associated with the presence of an exacerbated humoral response allowing the progression of the disease [92,93].

Illustratively, the positive skin test (late hypersensitivity reaction) for Leishmania spp. in dogs is a good indicator of resistance to infection, and can be used as a prognostic factor [94,95].

The mechanisms of cellular immune response in the natural infection canine leishmaniasis are different from those found in models where the classical Th1/Th2 response paradigm is associated with resistance or susceptibility [96]. Although not following the classic paradigm, some studies associate asymptomatic infection in dogs with the activation of Th1 cells that produce IFN $\gamma$, IL-2 and TNFa $[89,91]$. Furthermore, the cytokine profile in blood cell culture (PBMC) of infected asymptomatic dogs experimentally with $L$. infantum, shows predominantly Th1 response, mediated by expression of IL-2, IFN $\gamma$ and IL-18, but absence of IL-4 expression [35]. In this way, the parasites are killed by macrophages activated by lymphocytes producing IFN $\gamma$ through a mechanism dependent on nitric oxide production [97]. However, there is evidence that IFN- $\gamma$ increases in the early stages of infection but is not sufficient to prevent disease and that levels increase as a consequence of infection, regardless of clinical symptomatology [97,98].

Both asymptomatic and symptomatic dogs are able to produce cytokines from Th1 and Th2 profiles, and these profiles can coexist in CVL [99]. Thus, studies on the expression of cytokines in CVL have conflicting results that may be related to the compartmentalization of the response in the different tissues evaluated. Alves et al. [100] demonstrated the gene expression of IFN- $\gamma$ and TNF- $\alpha$ in asymptomatic dogs and IL-10 and TGF- $\beta$ in symptomatic dogs. The association of parasite load, clinical evolution, gene expression and synthesis of certain cytokines such as IFN $\gamma$, IL-2, IL-6, IL-10 and IL-12 has already been demonstrated [91,101-104]. Another study showed that increased IL-4 gene expression in peripheral blood mononuclear cells after six months of infection was quantitatively similar in both asymptomatic and symptomatic dogs [105]. In symptomatic dogs infected with $L$. infantum, no correlation was found between serum TNF- $\alpha$ level and active disease [102]. Unlike human and murine leishmaniasis, in CVL no difference was observed between levels of IL-10 in the tissues and the expression of IL-4 in the bone marrow of naturally infected dogs, especially those most severely affected, suggests an association between IL-4 and disease [97]. However, when analyzing the relationship between skin parasite density and the expression of mRNA for IL-10 in skin, it is observed a positive correlation between high burden and IL-10 expression [106]. In summary, the immunological mechanisms responsible for the resistance or progression of CVL and the detection of cytokine synthesis and its association with $L$. infantum infection are still controversial.

The understanding of the role of Th1 and Th2 subpopulations in the different tissues is crucial to comprehend the profile of immune response induced by the infection. In fact, the immune response to the parasite is not identical in any host system, but organ-specific [107]. The liver is the site of resolution of the acute infection, exhibits minimal tissue damage and resistance to reinfection, whereas the spleen becomes a site of persistence of the parasite as evidenced in a murine model of infection [67].

The spleen is among a major organ affected in CVL and is largely responsible for the immune response to infection, but the knowledge of the immunopathological mechanisms involved is limited, with most studies focused on the murine model of experimental infection. It is an important secondary large-volume lymphoid organ with primary function of responding to systemic pathogens [108]. The lymphoid tissue is highly organized and the disorganization of the splenic architecture in dogs with VL has been associated with the progression of the disease and the reduction of the expression of several chemokines and their receptors [109]. The mRNA levels of a wide variety of cytokines (IFN $\gamma$, TNFa, IL-4, IL-5, IL-10, IL-12, IL-18, TGF $\beta$ ), transcription factors (Tbet and GATA3), and chemokines (IP-10, RANTES, MIP-1a, MCP-1) were evaluated in the spleen of naturally and experimentally infected dogs [99,110]. It has been suggested that during $L$. infantum infection, a Th1/Th2 mixed response occurs in the spleen of symptomatic and oligosymptomatic dogs, insufficient to control the parasite locally. The authors showed that the high expression of IFN- $\gamma$ in the spleen did not eliminate the parasites completely, since a new parasite load from other sites, where IFN- $\gamma$ is not elevated, is constantly released into the spleen [111].

One of the most relevant organs involved in the parasite-host interface during $L$. infantum infection is the hepatic compartment. Few studies have quantified the production of cytokines and 
Citation: Fiuza JA, Gaze ST (2018) Immune Response Profile in Susceptibility and Protection in Visceral Leishmaniasis. J Immuno Biol 3: 1000139. doi:10.4172/2476-1966.1000139

Page 4 of 10

chemokines in the liver of infected dogs. The mRNA levels of CCL1, CCL17, CCL26, CCR3, CCR4, CCR5, CCR6 and CCR8 were higher in asymptomatic dogs as well as the synthesis of IFN- $\gamma$, IL-10 and TGF$\beta 1[99,112]$. On the other hand, it seems that the infection alone causes an increase in the synthesis of IL-4 and IL-10 in the liver, independent of symptomatology, with increased TNF- $\alpha$ level in symptomatic dogs, which was not observed in the spleen. In addition, the parasite burden of the liver is lower than in the spleen [113]. In the liver, the presence of granulomas, in different degrees of maturation in infected dogs, is a reaction of this organ to try to control the proliferation of parasites, and in the murine model TNFa is involved in the formation of hepatic granulomas $[67,114]$. The presence of granulomas is also observed in human VL and CVL [115].

\section{Immune Response Profile after Different Vaccination Approaches}

The control of LV is dependent of early diagnosis, treatment of infected individuals, and control of vectors and outbreaks in domestic reservoirs [2]. These measures together could eliminate or drastically reduce transmission $[116,117]$ when used over a long period of time [118]. However, the number of available drugs is limited, most overpriced, have toxic side effects or prove ineffective due to coinfection with HIV or induce emergence of resistant strains. In addition, the vector control methods available are not so efficient. Therefore, vaccination is the most effective method for the control of zoonotic LV. The application of an effective vaccine in human/dogs can also drastically reduce the transmission of $L$. infantum [119]. The development of vaccines against human and canine infection has been the target of many research groups $[50,61,120,121]$.

It has been demonstrated that the treatment of Leishmania infection confers a strong immunity against reinfection in cutaneous species $[47,122]$, the partial protection observed in animal models after immunization with different recombinant or crude antigens $[50,123,124]$ and protection against infection resulting from the leishmanization process [125]. However, despite the extensive search for vaccine development against leishmaniasis in recent decades, no vaccine against human leishmaniasis, whether cutaneous or visceral, is available for prophylactic use.

Between the different methodologies, the vaccination approaches include killed or live attenuated Leishmania parasite (first generation), recombinant Leishmania proteins (second generation), DNA encoding Leishmania proteins (third generation), and immunomodulators [61,126-128] Here is tabled the available immunization studies according to the animal model and the protection observed (Table 1).

\begin{tabular}{|c|c|c|c|c|}
\hline Immunization & Animal model & Profile of immune response & Protection & Reference \\
\hline L. major antigens+BCG & Clinical trial & - & Partial protection & [129] \\
\hline L. major antigens+BCG & Dogs & - & Partial protection & [130] \\
\hline L. braziliensis+BCG & Dogs & Cell proliferation and IFN-ץ production & Partial protection & [131] \\
\hline Leish 111 (LelF+TSA+LmSTI1)+MPL & Dogs & $\operatorname{lgG} 1$ and $\lg \mathrm{G} 2$ production & - & [132] \\
\hline MML & Dogs & - & $5 / 8$ protected dogs & [133] \\
\hline H1, HASPB1, H1+HASPB1 & Dogs & Antibody response & Partial protection & [133] \\
\hline Protein $Q$ chimera+BCG & Dogs & DTH response & Protection & [134] \\
\hline Multicomponent LBSap vaccine & Mice & Humoral and cellular response & Partial protection & [135] \\
\hline LBSapSal & Dogs & NO and Th1 cytokines response & Protection & [136] \\
\hline LBSap & Dogs & Cell proliferation, IFN-y production & Protection & {$[137,138]$} \\
\hline pCl-neo-LACK+MVA or M65 & $\begin{array}{l}\text { Human } \\
\text { Hamsters }\end{array}$ & Th1-type response & Protection & [139] \\
\hline rA2+Alum+CPG & Mice & High IgG, IgG1, IgG2, IFN-g and IL-10 & $\begin{array}{l}82 \% \quad \text { decrease } \\
\text { spleen }\end{array}$ & [140] \\
\hline \multicolumn{5}{|l|}{$\begin{array}{l}\text { CL-14 (Trypanosoma cruzi CL-14 non-virulent } \\
\text { strain)+A2 }\end{array}$} \\
\hline $\begin{array}{l}\text { Th1 responses with enhanced IFN- } \mathrm{Y}, \mathrm{IL}-12 \text {, } \\
\text { nitric oxide, }\end{array}$ & Mice & $\begin{array}{l}\text { Th1 responses with enhanced IFN-, IL-12, nitric } \\
\text { oxide, }\end{array}$ & Protection & {$[141,142]$} \\
\hline $\lg$ G2a/IgG1 ratio and reduced IL-4 and IL-10 & & IgG2a/lgG1 ratio and reduced IL-4 and IL-10 & & \\
\hline responses & & responses & & \\
\hline $\begin{array}{l}\text { Th1 responses with enhanced IFN- } \gamma \text {, IL-12, } \\
\text { nitric oxide, }\end{array}$ & & High IFN-g, IL-12, NO, IgG2/lgG1 ratio & & \\
\hline $\operatorname{lgG} 2 \mathrm{a} / \operatorname{lgG} 1$ ratio and reduced IL-4 and IL-10 & & Low IL-10, IL-4 & & \\
\hline
\end{tabular}


Citation: Fiuza JA, Gaze ST (2018) Immune Response Profile in Susceptibility and Protection in Visceral Leishmaniasis. J Immuno Biol 3: 1000139. doi:10.4172/2476-1966.1000139

Page 5 of 10

\begin{tabular}{|c|c|c|c|c|}
\hline \multicolumn{5}{|l|}{ responses } \\
\hline \multicolumn{5}{|l|}{$\begin{array}{l}\text { Th1 responses with enhanced IFN- }- \text {, IL-12, } \\
\text { nitric oxide, }\end{array}$} \\
\hline \multicolumn{5}{|l|}{$\operatorname{lgG} 2 \mathrm{a} / \operatorname{lgG} 1$ ratio and reduced IL- 4 and IL-10 } \\
\hline \multicolumn{5}{|l|}{ responses } \\
\hline \multicolumn{5}{|l|}{ gp63 } \\
\hline gp63+HSP70 DNA & Mice & High IFN-g & - & [143] \\
\hline Proteophosphoglycan & Hamsters & NO and pro inflammatory cytokines & $80 \%$ of protection & [144] \\
\hline KMP-11 & Mice/Hamsters & $\mathrm{CD}^{+}{ }^{+}$and $\mathrm{CD} 8^{+} \mathrm{T}$ cells producing IFN-g, IL- 12 , TNF-a & Protection & [145-148] \\
\hline Amastigote gene & Mice & IgG, pro inflammatory cytokines & - & [149] \\
\hline KMP-11+Ljm19 & Hamsters & High IFN-y/IL-10 & Protection & [147] \\
\hline Centrin deleted live parasite $L$. donovani & Mice, hamsters, dogs & $\begin{array}{l}\text { High IFN-g, IL-12, TNF-a, IgG, IgG1, IgG2, } \mathrm{T} \text { cell } \\
\text { proliferation }\end{array}$ & Protection & {$[150-154]$} \\
\hline $\begin{array}{l}\text { Ascorbic acid-deficient live mutants of } L \text {. } \\
\text { donovani }\end{array}$ & Mice & T cell proliferation, pro inflammatory cytokines & Protection & [155] \\
\hline p27 gene knockout $L$. Donovani parasites & Mice & $\mathrm{T}$ cell proliferation, pro inflammatory cytokines, NO & Protection & [156] \\
\hline L. major (ALM)+BCG & Mice & Antibody production, DTH response & Protection & [125] \\
\hline KBMA $L$. infantum and $L$. chagasi & Mice & Th1 cytokine pattern & Partial protection & [157] \\
\hline Leishmune (FML) & Mice, dogs & $\begin{array}{l}\text { High lymph proliferative response and } \lg G 2 \\
\text { production }\end{array}$ & Partial protection & [158] \\
\hline Leish F1 & Clinical trial & Th1 response & Safe & [159] \\
\hline Leish 111f+MPL & Clinical trial & Th1 response & Protection & [160] \\
\hline HASPB1 & Mice & Th1 response & Protection & [161] \\
\hline rSMT & Mice & Th1 response & Protection & [162] \\
\hline A2 & Mice & High IFN-y production & Protection & [163] \\
\hline LD91+LD72+ LD51+LD31 & Mice & High pro inflammatory cytokines production & Protection & [164] \\
\hline TRYP & Mice & $\lg G$ and $\lg G 2$ production & Partial protection & [165] \\
\hline ORFF & Hamsters & IFN-y and IL-12 production & Partial protection & [166] \\
\hline LPG 3 & Mice & Mixed Th1/Th2 response & Partial protection & [167] \\
\hline LEISHDNAVAX & Mice & IgG production & Partial protection & [168] \\
\hline
\end{tabular}

Table 1: Immunization studies to VL according to animal model, immune response profile and protection

\section{Conclusions}

The pattern of immune response is well studied in murine and human, whose Th1/Th2 paradigm is well established. In the murine model of leishmaniasis, Th1 cells secrete IL-2, IFN- $\gamma$ and TNF- $\alpha$ and are associated with resistance and infection control, whereas Th2 cells secrete IL-4 and IL-10, and are responsible for the susceptibility and progression of the disease In human VL, the immune response Th2 is represented by the low synthesis of IFN $\gamma$ and by the increase of IL-4 levels. In addition, IL-10 has been indicated as one of the major cytokines suppressors of the protective immune response, both in murine models and in human VL. Although some evidence demonstrates the feasibility of vaccination against leishmaniasis, the differences among the host species and the organs affected by the disease creates difficulties to develop a broad vaccine [169-177]. Those particularities still need more studies and a better understanding to develop a well-established vaccine to VL.

\section{References}

1. Alvar J, Vélez ID, Bern C, Herrero M, Desjeux P, et al. (2012) Leishmaniasis worldwide and global estimates of its incidence. PLoS One 7: e35671. 
2. Desjeux P (1996) Leishmaniasis. Public health aspects and control. Clin Dermatol 14: 417-423.

3. Mathers CD, Ezzati M, Lopez AD (2007) Measuring the burden of neglected tropical diseases: the global burden of disease framework. PLoS Negl Trop Dis 1: el14.

4. Badaro R, Jones TC, Carvalho EM, Sampaio D, Reed SG, et al. (1986) New perspectives on a subclinical form of visceral leishmaniasis. J Infect Dis 154: 1003-1011.

5. Okwor I, Uzonna JE (2013) The immunology of Leishmania/HIV coinfection. Immunol Res 56: 163-171.

6. Bryceson A (2001) A policy for leishmaniasis with respect to the prevention and control of drug resistance. Trop Med Int Health 6: 928-934.

7. Sundar S, Rai M (2002) Advances in the treatment of leishmaniasis. Curr Opin Infect Dis 15: 593-598.

8. Bryceson A (2001) Current issues in the treatment of visceral leishmaniasis. Med Microbiol Immunol 190: 81-84.

9. Tesh RB (1995) Control of zoonotic visceral leishmaniasis: is it time to change strategies? Am J Trop Med Hyg 52: 287-292.

10. Fernandes AP, Costa MM, Coelho EA, Michalick MS, de Freitas E, et al. (2008) Protective immunity against challenge with Leishmania (Leishmania) chagasi in beagle dogs vaccinated with recombinant A2 protein. Vaccine 26: 5888-5895.

11. Moreno J, Vouldoukis I, Martin V, McGahie D, Cuisinier AM, et al. (2012) Use of a LiESP/QA-21 vaccine (CaniLeish) stimulates an appropriate Th1-dominated cell-mediated immune response in dogs. PLoS Negl Trop Dis 6: el683.

12. Fernández Cotrina J, Iniesta V, Monroy I, Baz V, Hugnet C, et al. (2018) A large-scale field randomized trial demonstrates safety and efficacy of the vaccine LetiFend $^{\bullet}$ against canine leishmaniosis. Vaccine 36: 1972-1982.

13. Toepp A, Larson M, Grinnage-Pulley T, Bennett C, Anderson M, et al. (2018) Safety Analysis of Leishmania Vaccine Used in a Randomized Canine Vaccine/Immunotherapy Trial. Am J Trop Med Hyg 98: 1332-1338.

14. Awasthi A, Mathur RK, Saha B (2004) Immune response to Leishmania infection. Indian J Med Res 119: 238-258.

15. Goto H1, Lindoso JA (2004) Immunity and immunosuppression in experimental visceral leishmaniasis. Braz J Med Biol Res 37: 615-623.

16. Mauel J (1992) Evaluation of assay procedures measuring macrophage stimulation by immunomodulators in vitro. Dev Biol Stand 77: 71-77.

17. Bogdan C, Röllinghoff M (1998) The immune response to Leishmania: mechanisms of parasite control and evasion. Int J Parasitol 28: 121-134.

18. Rogers KA, DeKrey GK, Mbow ML, Gillespie RD, Brodskyn CI, et al. (2002) Type 1 and type 2 responses to Leishmania major. FEMS Microbiol Lett 209: 1-7.

19. Alexander J, Bryson K (2005) T helper (h)1/Th2 and Leishmania: paradox rather than paradigm. Immunol Lett 99: 17-23.

20. Coler RN, Reed SG (2005) Second-generation vaccines against leishmaniasis. Trends Parasitol 21: 244-249.

21. Boehm U, Klamp T, Groot M, Howard JC (1997) Cellular responses to interferon-gamma. Annu Rev Immunol 15: 749-795.

22. Sacks D, Noben-Trauth N (2002) The immunology of susceptibility and resistance to Leishmania major in mice. Nat Rev Immunol 2: 845-858.

23. Tripathi P, Singh V, Naik S (2007) Immune response to leishmania: paradox rather than paradigm. FEMS Immunol Med Microbiol 51: 229-242.

24. Soong L, Henard CA, Melby PC (2012) Immunopathogenesis of nonhealing American cutaneous leishmaniasis and progressive visceral leishmaniasis. Semin Immunopathol 34: 735-751.

25. Faleiro RJ, Kumar R, Hafner LM, Engwerda CR (2014) Immune regulation during chronic visceral leishmaniasis. PLoS Negl Trop Dis 8: e2914.

26. Rosas LE, Satoskar AA, Roth KM, Keiser TL, Barbi J, et al. (2006) Interleukin-27R (WSX-1/T-cell cytokine receptor) gene-deficient mice display enhanced resistance to leishmania donovani infection but develop severe liver immunopathology. Am J Pathol 168: 158-169.

27. Sacks DL, Perkins PV (1984) Identification of an infective stage of Leishmania promastigotes. Science 223: 1417-1419.

28. Deak E, Jayakumar A, Cho KW, Goldsmith-Pestana K, Dondji B, et al. (2010) Murine visceral leishmaniasis: IgM and polyclonal B-cell activation lead to disease exacerbation. Eur J Immunol 40: 1355-1368.

29. Ronet C, Hauyon-La Torre Y, Revaz-Breton M, Mastelic B, TacchiniCottier F, et al. (2010) Regulatory B cells shape the development of Th2 immune responses in $\mathrm{BALB} / \mathrm{c}$ mice infected with Leishmania major through IL-10 production. J Immunol 184: 886-894.

30. Smelt SC, Cotterell SE, Engwerda CR, Kaye PM (2000) B cell-deficient mice are highly resistant to Leishmania donovani infection, but develop neutrophil-mediated tissue pathology. J Immunol 164: 3681-3688.

31. Rodrigues V, Laforge M, Campillo-Gimenez L, Soundaramourty C, Correia-de-Oliveira A, et al. (2014) Abortive $\mathrm{T}$ follicular helper development is associated with a defective humoral response in Leishmania infantum-infected macaques. PLoS Pathog 10: e1004096.

32. Costa CH Pereira HF, Araujo V (1990) [Visceral leishmaniasis epidemic in the State of Piauí, Brazil, 1980-1986]. Rev Saude Public 24: 361-372.

33. Hailu A, van der Poll T, Berhe N, Kager PA (2004) Elevated plasma levels of interferon (IFN)-gamma, IFN-gamma inducing cytokines, and IFNgamma inducible CXC chemokines in visceral leishmaniasis. Am J Trop Med Hyg 71: 561-567.

34. Grimaldi G Jr, Tesh RB (1993) Leishmaniases of the New World: current concepts and implications for future research. Clin Microbiol Rev 6: 230-250.

35. Olivier M, Gregory DJ, Forget G (2005) Subversion mechanisms by which Leishmania parasites can escape the host immune response: a signaling point of view. Clin Microbiol Rev 18: 293-305.

36. McMahon-Pratt D, Alexander J (2004) Does the Leishmania major paradigm of pathogenesis and protection hold for New World cutaneous leishmaniases or the visceral disease? Immunol Rev 201: 206-224.

37. Gantt KR, Goldman TL, McCormick ML, Miller MA, Jeronimo SM, et al. (2001) Oxidative responses of human and murine macrophages during phagocytosis of Leishmania chagasi. J Immunol 167: 893-901.

38. Pinelli E, Rutten VPMG, Bruysters M, Moore PF, Ruitenberg EJ (1999) Compensation for decreased expression of B7 molecules on Leishmania infantum-infected canine macrophages results in restoration of parasitespecific T-cell proliferation and gamma interferon production. Infect Immun 67: 237-243.

39. Sacks D, Sher A (2002) Evasion of innate immunity by parasitic protozoa. Nat Immunol 3: 1041-1047.

40. Goto H, Prianti M (2009) Immunoactivation and immunopathogeny during active visceral leishmaniasis. Rev Inst Med Trop Sao Paulo 51: 241-246.

41. Almeida MA, Jesus EE, Sousa-Atta ML, Alves LC, Berne ME, et al. (2005) Antileishmanial antibody profile in dogs naturally infected with Leishmania chagasi. Vet Immunol Immunopathol 106: 151-158.

42. Carvalho EM, Sampaio D, Netto M (1992) Immunologic markers of clinical evolution in children recently infected with Leishmania donovani chagasi. J Infect Dis 165: 535-540.

43. Carvalho EM, Bacellar O, Brownell C, Regis T, Coffman RL, et al. (1994) Restoration of IFN-gamma production and lymphocyte proliferation in visceral leishmaniasis. J Immunol 152: 5949-5956.

44. Kharazmi A, Kemp K, Ismail A, Gasim S, Gaafar A, et al. (1999) T-cell response in human leishmaniasis. Immunol Lett 65: 105-108.

45. Saha S, Mondal S, Banerjee A, Ghose J, Bhowmick S, et al. (2006) Immune responses in kala-azar. Indian J Med Res 123: 245-266.

46. Cillari E, Agostino P (1995) In vivo and in vitro cytokine profiles and mononuclear cell subsets in Sicilian patients with active visceral leishmaniasis. Cytokine 7: 740-745.

47. Peruhype-Magalhães V, Filho OA, Prata A (2006) Mixed inflammatory/ regulatory cytokine profile marked by simultaneous raise of interferongamma and interleukin-10 and low frequency of tumour necrosis factor- 
alpha(+) monocytes are hallmarks of active human visceral Leishmaniasis due to Leishmania chagasi infection. Clin Exp Immunol 146: 124-132.

48. Palatnik-de-Sousa CB, Ade F, Nico D (2008) FML vaccine against canine visceral leishmaniasis: from second-generation to synthetic vaccine. Expert Rev Vaccines 7: 833-851.

49. Ghalib HW, Piuvezam MR, Skeiky YA, Siddig M, Hashim FA, et al. (1993) Interleukin 10 production correlates with pathology in human Leishmania donovani infections. J Clin Invest 92: 324-329.

50. Holaday BJ (1999) Immunotherapy for visceral leishmaniasis: ability of factors produced during anti-leishmania responses of skin test positive adults to inhibit peripheral blood mononuclear cell activities associated with visceral leishmaniasis. Mem Inst Oswaldo Cruz 94: 55-66.

51. Murphy ML, Wille U, Villegas EN, Hunter CA, Farrell JP (2001) IL-10 mediates susceptibility to Leishmania donovani infection. Eur J Immunol 31: 2848-2856.

52. Nylen S, Sacks D Interleukin-10 and the pathogenesis of human visceral leishmaniasis. Trends Immunol, 2007. 28: p.378-384.

53. Nylen S, Maurya R, Eidsmo L, Manandhar KD, Sundar S, et al. (2007) Splenic accumulation of IL-10 mRNA in $\mathrm{T}$ cells distinct from CD4+CD25+ (Foxp3) regulatory $\mathrm{T}$ cells in human visceral leishmaniasis. J Exp Med 204: 805-817.

54. Rodrigues V, Cordeiro-da-Silva A, Laforge M, Silvestre R, Estaquier J (2016) Regulation of immunity during visceral Leishmania infection. Parasit Vectors 9: 118

55. Murray HW, Moreira AL, Lu CM, DeVecchio JL, Matsuhashi M, et al. (2003) Determinants of response to interleukin-10 receptor blockade immunotherapy in experimental visceral leishmaniasis. J Infect Dis 188: 458-464.

56. Vouldoukis I, Bécherel PA, Riveros-Moreno V, Arock M, da Silva O, et al. (1997) Interleukin-10 and interleukin-4 inhibit intracellular killing of Leishmania infantum and Leishmania major by human macrophages by decreasing nitric oxide generation. Eur J Immunol 27: 860-865.

57. Bhattacharyya S, Ghosh S, Jhonson PL, Bhattacharya SK, Majumdar S (2001) Immunomodulatory role of interleukin-10 in visceral leishmaniasis: defective activation of protein kinase C-mediated signal transduction events. Infect Immun 69: 1499-1507.

58. Singh OP, Stober CB, Singh AK, Blackwell JM, Sundar S (2012) Cytokine responses to novel antigens in an Indian population living in an area endemic for visceral leishmaniasis. PLoS Negl Trop Dis 6: e1874.

59. Singh OP, Gidwani K, Kumar R, Nylén S, Jones SL (2012) Reassessment of immune correlates in human visceral leishmaniasis as defined by cytokine release in whole blood. Clin Vaccine Immunol 19: 961-966.

60. Ato M, Stager S, Engwerda CR, Kaye PM (2002) Defective CCR7 expression on dendritic cells contributes to the development of visceral leishmaniasis. Nat Immunol 3: 1185-1191.

61. Ito S, Ansari P, Sakatsume M, Dickensheets H, Vazquez N, et al. (1999) Interleukin-10 inhibits expression of both interferon alpha- and interferon gamma- induced genes by suppressing tyrosine phosphorylation of STAT1. Blood 93: 1456-1463.

62. Wu J, Cunha FQ, Liew FY, Weiser WY (1993) IL-10 inhibits the synthesis of migration inhibitory factor and migration inhibitory factor-mediated macrophage activation. J Immunol 151: 4325-4332.

63. Vouldoukis I, Drapier JC, Nüssler AK, Tselentis Y, Da Silva OA, et al. (1996) Canine visceral leishmaniasis: successful chemotherapy induces macrophage antileishmanial activity via the L-arginine nitric oxide pathway. Antimicrob Agents Chemother 40: 253-256.

64. Honstettre A, Imbert G, Ghigo E, Gouriet F, Capo C, et al. (2003) Dysregulation of cytokines in acute $\mathrm{Q}$ fever: role of interleukin-10 and tumor necrosis factor in chronic evolution of Q fever. J Infect Dis 187: 956-962.

65. Stanley AC, Engwerda CR (2007) Balancing immunity and pathology in visceral leishmaniasis. Immunol Cell Biol 85: 138-147.

66. Rosas LE, Snider HM, Barbi J, Satoskar AA, Lugo-Villarino G (2006) Cutting edge: STAT1 and T-bet play distinct roles in determining outcome of visceral leishmaniasis caused by Leishmania donovani. J Immunol 177: 22-25.

67. Bacellar O, Brodskyn C, Guerreiro J, Barral-Netto M, Costa CH, et al. (1996) Interleukin-12 restores interferon-gamma production and cytotoxic responses in visceral leishmaniasis. J Infect Dis 173: 1515-1518.

68. Carvalho LP, Passos S, Dutra WO, Soto M, Alonso C (2005) Effect of LACK and KMP11 on IFN-gamma production by peripheral blood mononuclear cells from cutaneous and mucosal leishmaniasis patients. Scand J Immunol 61: 337-342.

69. Gama ME, Costa JM, Gomes CM, Corbett CE (2004) Subclinical form of the American visceral leishmaniasis. Mem Inst Oswaldo Cruz 99: 889-893.

70. Carvalho EM, Bacellar OA, Reed S, Barral A, Rocha H (1988) Visceral leishmaniasis: a disease associated with inability of lymphocytes to activate macrophages to kill leishmania. Braz J Med Biol Res 21: 85-92.

71. Bacellar O, D'oliveira A Jr, Jerônimo S, Carvalho EM (2000) IL-10 and IL-12 are the main regulatory cytokines in visceral leishmaniasis. Cytokine 12: 1228-1231.

72. Costa DJ, Carvalho RM, Abbehusen M, Teixeira C, Pitombo M, et al. (2013) Experimental infection of dogs with Leishmania and saliva as a model to study Canine Visceral Leishmaniasis. PLoS One 8: e60535.

73. Peruhype-Magalhães V, Martins-Filho OA, Prata A, Silva Lde A, Rabello $A$, et al. (2005) Immune response in human visceral leishmaniasis: analysis of the correlation between innate immunity cytokine profile and disease outcome. Scand J Immunol 62: 487-495.

74. Gama ME, Gomes CM, Silveira FT, Laurenti MD, Gonçalves EG, et al. (2013) Severe visceral leishmaniasis in children: the relationship between cytokine patterns and clinical features. Rev Soc Bras Med Trop 46: 741-745.

75. Akdis M, Burgler S, Crameri R, Eiwegger T, Fujita H, et al. (2011) Interleukins, from 1 to 37 , and interferon- $\hat{I}^{3}$ : receptors, functions, and roles in diseases. J Allergy Clin Immunol 127: 701-721.

76. Khoshdel A, Alborzi A, Rosouli M, Taheri E, Kiany S, et al. (2009) Increased levels of IL-10, IL-12, and IFN- in patients with visceral leishmaniasis. Braz J Infect Dis 13: 44-46.

77. Costa MM, Penido M, dos Santos MS, Doro D, de Freitas E, et al. (2012) Improved canine and human visceral leishmaniasis immunodiagnosis using combinations of synthetic peptides in enzyme-linked immunosorbent assay. PLoS Negl Trop Dis 6: e1622.

78. Ansari NA, Kumar R, Gautam S, Nylen S, Singh OP, et al. (2011) IL-27 and IL-21 are associated with T cell IL-10 responses in human visceral leishmaniasis. J Immunol 186: 3977-3985.

79. Hunter CA, Kastelein R (2012) Interleukin-27: balancing protective and pathological immunity. Immunity 37: 960-969.

80. Anstead GM, Chandrasekar B, Zhao W, Yang J, Perez LE, et al. (2001) Malnutrition alters the innate immune response and increases early visceralization following Leishmania donovani infection. Infect Immun 69: 4709-4718

81. Kelly LE, Patterson BJ (2006) Childhood nutrition: perceptions of caretakers in a low-income urban setting. J Sch Nurs 22: 345-351.

82. Hassan MF, Zhang Y, Engwerda CR, Kaye PM, Sharp H, et al. (2006) The Schistosoma mansoni hepatic egg granuloma provides a favorable microenvironment for sustained growth of Leishmania donovani. Am J Pathol 169: 943-953.

83. O'Neal SE, Guimarães LH, Machado PR, Alcântara L, Morgan DJ, et al. (2007) Influence of helminth infections on the clinical course of and immune response to Leishmania braziliensis cutaneous leishmaniasis. J Infect Dis 195: 142-148.

84. Liu L, Wang L, Zhao Y, Wang Y, Wang Z, et al. (2006) Testosterone attenuates p38 MAPK pathway during Leishmania donovani infection of macrophages. Parasitol Res 99: 189-193.

85. Shiddo SA, Aden Mohamed A, Akuffo HO, Mohamud KA, Herzi AA, et al. (1995) Visceral leishmaniasis in Somalia: prevalence of markers of infection and disease manifestations in a village in an endemic area. Trans R Soc Trop Med Hyg 89: 361-365. 
Page 8 of 10

86. Jeronimo SM, Duggal P, Braz RF, Cheng C, Monteiro GR, et al. (2004) An emerging peri-urban pattern of infection with Leishmania chagasi, the protozoan causing visceral leishmaniasis in northeast Brazil. Scand J Infect Dis 36: 443-449.

87. Pinelli E, Killick-Kendrick R, Wagenaar J, Bernadina W, del Real G, et al. (1994) Cellular and humoral immune responses in dogs experimentally and naturally infected with Leishmania infantum. Infect Immun, 62: 229-235.

88. Solano-Gallego L, Llull J, Ramos G, Riera C, Arboix M, et al. (2000) The Ibizian hound presents a predominantly cellular immune response against natural Leishmania infection. Vet Parasitol 90: 37-45.

89. Santos-Gomes GM, Rosa R, Leandro C, Cortes S, Romão P, et al. (2002 ) Cytokine expression during the outcome of canine experimental infection by Leishmania infantum. Vet Immunol Immunopathol 88: 21-30.

90. Reis AB, Giunchetti RC, Carrillo E, Martins-Filho OA, Moreno J, et al. (2010) Immunity to Leishmania and the rational search for vaccines against canine leishmaniasis. Trends Parasitol 26: 341-349.

91. Reis AB, Martins-Filho OA, Teixeira-Carvalho A, Carvalho MG, Mayrink W, et al. (2006) Parasite density and impaired biochemical/hematological status are associated with severe clinical aspects of canine visceral leishmaniasis. Res Vet Sci 81: 68-75.

92. Dos-Santos WL, Jesus EE, Paranhos-Silva M, Pereira AM, Santos JC, et al. (2008) Associations among immunological, parasitological and clinical parameters in canine visceral leishmaniasis: Emaciation, spleen parasitism, specific antibodies and leishmanin skin test reaction. Vet Immunol Immunopathol 123: 251-259.

93. Falqueto A, Ferreira AL, dos Santos CB, Porrozzi R, da Costa MV, et al. (2009) Cross-sectional and longitudinal epidemiologic surveys of human and canine Leishmania infantum visceral infections in an endemic rural area of southeast Brazil (Pancas, Espirito Santo). Am J Trop Med Hyg 80: 559-565.

94. Panaro MA, Brandonisio O, Cianciulli A, Cavallo P, Lacasella V, et al. (2009) Cytokine expression in dogs with natural Leishmania infantum infection. Parasitology 136: 823-831.

95. Quinnell RJ, Courtenay O, Davidson S, Garcez L, Lambson B, et al. (2001) Detection of Leishmania infantum by PCR, serology and cellular immune response in a cohort study of Brazilian dogs. Parasitology 122: 253-261.

96. Travi BL, Osorio EY, Saldarriaga OA, Cadena H, Tabares CJ, et al. Clinical, parasitologic, and immunologic evolution in dogs experimentally infected with sand fly-derived Leishmania chagasi promastigotes. Am J Trop Med Hyg 81: 994-1003.

97. Correa AP, Dossi AC, de Oliveira Vasconcelos R, Munari DP, de Lima VM (2007) Evaluation of transformation growth factor beta1, interleukin-10, and interferon-gamma in male symptomatic and asymptomatic dogs naturally infected by Leishmania (Leishmania) chagasi. Vet Parasitol 143: 267-274.

98. Clemente WT, Rabello A, Faria LC, Peruhype-Magalhães V, Gomes LI, et al. (2014) High prevalence of asymptomatic Leishmania spp. infection among liver transplant recipients and donors from an endemic area of Brazil. Am J Transplant 14: 96-101.

99. Chamizo C, Moreno J, Alvar J (2005) Semi-quantitative analysis of cytokine expression in asymptomatic canine leishmaniasis. Vet Immunol Immunopathol 103: 67-75.

100. Olivier M, Gregory DJ, Forget G (2005) Subversion mechanisms by which Leishmania parasites can escape the host immune response: a signaling point of view. Clin Microbiol Rev 18: 293-305.

101. Pinelli E, Rutten VP, Bruysters M, Moore PF, Ruitenberg EJ (1999) Compensation for decreased expression of B7 molecules on Leishmania infantum-infected canine macrophages results in restoration of parasitespecific T-cell proliferation and gamma interferon production. Infect Immun 67: 237-243.

102. Goto H, Prianti M (2009) Immunoactivation and immunopathogeny during active visceral leishmaniasis. Rev Inst Med Trop Sao Paulo 51: 241-246.
103. Almeida MA, Jesus EE, Sousa-Atta ML, Alves LC, Berne ME, et al. (2005) Antileishmanial antibody profile in dogs naturally infected with Leishmania chagasi. Vet Immunol Immunopathol 106: 151-158.

104. Carvalho EM, Barral A, Pedral-Sampaio D, Barral-Netto M, Badaró R, et al. (1992) Immunologic markers of clinical evolution in children recently infected with Leishmania donovani chagasi. J Infect Dis 165: 535-540.

105. Cillari E, Vitale G, Arcoleo F, D'Agostino P, Mocciaro C, et al. (1995) In vivo and in vitro cytokine profiles and mononuclear cell subsets in Sicilian patients with active visceral leishmaniasis. Cytokine 7: 740-745.

106. Peruhype-Magalhães V, Martins-Filho OA, Prata A, Silva Lde A, Rabello A, et al. (2006) Mixed inflammatory/regulatory cytokine profile marked by simultaneous raise of interferon-gamma and interleukin-10 and low frequency of tumour necrosis factor-alpha(+) monocytes are hallmarks of active human visceral Leishmaniasis due to Leishmania chagasi infection. Clin Exp Immunol 146: 124-132.

107. Palatnik-de-Sousa CB, Barbosa Ade F, Oliveira SM, Nico D, Bernardo RR, et al. (2008) FML vaccine against canine visceral leishmaniasis: from second-generation to synthetic vaccine. Expert Rev Vaccines 7: 833-851.

108. Alves CF, de Amorim IF, Moura EP, Ribeiro RR, Alves CF, et al. Expression of IFN-gamma, TNF-alpha, IL-10 and TGF-beta in lymph nodes associates with parasite load and clinical form of disease in dogs naturally infected with Leishmania (Leishmania) chagasi. Vet Immunol Immunopathol 128: 349-358.

109. Barbiéri CL (2006) Immunology of canine leishmaniasis. Parasite Immunol 28: 329-337.

110. de Lima VM, Peiro JR de Oliveira Vasconcelos R (2007) IL-6 and TNFalpha production during active canine visceral leishmaniasis. Vet Immunol Immunopathol 115: 189-193.

111. Lage RS, Oliveira GC, Busek SU, Guerra LL, Giunchetti RC, et al. (2007) Analysis of the cytokine profile in spleen cells from dogs naturally infected by Leishmania chagasi. Vet Immunol Immunopathol 115: 135-145.

112. Manna L, Reale S, Picillo E, Vitale F, Gravino AE, et al. (2008) Interferongamma (INF-gamma), IL4 expression levels and Leishmania DNA load as prognostic markers for monitoring response to treatment of leishmaniotic dogs with miltefosine and allopurinol. Cytokine 44: 288-292.

113. Manna L, Reale S, Viola E, Vitale F, Foglia Manzillo V, et al. (2006) Leishmania DNA load and cytokine expression levels in asymptomatic naturally infected dogs. Vet Parasitol 142: 271-280.

114. Menezes-Souza D, Correa-Oliveira R, Guerra-Sa R, Giunchetti RC, Teixeira-Carvalho A, et al. Cytokine and transcription factor profiles in the skin of dogs naturally infected by Leishmania (Leishmania) chagasi presenting distinct cutaneous parasite density and clinical status. Vet Parasitol 177: 39-49.

115. Reis AB, Martins-Filho OA, Teixeira-Carvalho A, Giunchetti RC, Carneiro CM, et al. (2009) Systemic and compartmentalized immune response in canine visceral leishmaniasis. Vet Immunol Immunopathol 128: p. 87-95.

116. Mebius RE, Kraal G (2005) Structure and function of the spleen. Nat Rev Immunol 5: 606-616.

117. Santana CC, Vassallo J, de Freitas LA, Oliveira GG, Pontes-de-Carvalho LC, et al. (2008) Inflammation and structural changes of splenic lymphoid tissue in visceral leishmaniasis: a study on naturally infected dogs. Parasite Immunol 30: 515-524.

118. Silva KL, Melo LM, Perosso J, Oliveira BB, Santos PS, et al. (2013) CD95 (FAS) and CD178 (FASL) induce the apoptosis of CD4+ and CD8+ cells isolated from the peripheral blood and spleen of dogs naturally infected with Leishmania spp. Vet Parasitol 197: 470-476.

119. Strauss-Ayali D, Baneth G, Jaffe CL (2007) Splenic immune responses during canine visceral leishmaniasis. Vet Res 38: 547-564.

120. Nascimento MS, Albuquerque TD, Do-Valle-Matta MA, Caldas IS, Diniz LF, et al. (2013) Naturally Leishmania infantum-infected dogs display an overall impairment of chemokine and chemokine receptor expression during visceral leishmaniasis. Vet Immunol Immunopathol 153: 202-208. 
121. Michelin A, Henderson DK (2010) Infection control guidelines for prevention of health care-associated transmission of hepatitis $\mathrm{B}$ and $\mathrm{C}$ viruses. Clin Liver Dis 14: 119-136.

122. Giunchetti RC, Mayrink W, Carneiro CM, Corrêa-Oliveira R, MartinsFilho OA, et al. (2008) Histopathological and immunohistochemical investigations of the hepatic compartment associated with parasitism and serum biochemical changes in canine visceral leishmaniasis. Res Vet Sci 84: 269-277.

123. Geramizadeh B, Jahangiri R, Moradi E (2011) Causes of hepatic granuloma: a 12-year single center experience from southern Iran. Arch Iran Med 14: 288-289.

124. Jeronimo SM, Teixeira MJ, Sousa Ad, Thielking P, Pearson RD, et al. (2000) Natural history of Leishmania (Leishmania) chagasi infection in Northeastern Brazil: long-term follow-up. Clin Infect Dis 30: 608-609.

125. Palatnik-de-Sousa CB, dos Santos WR, França-Silva JC, da Costa RT, Reis $\mathrm{AB}$, et al. (2001) Impact of canine control on the epidemiology of canine and human visceral leishmaniasis in Brazil. Am J Trop Med Hyg 65: 510-517.

126. Magalhaes PA, Mayrink W, da Costa CA, Melo MN, Dias M et al. (1980) Kala-azar in the Rio Doce, Minas Gerais area. Results of prophylactic measures. Rev Inst Med Trop Sao Paulo 22: 197-202.

127. Dye C (1996) The logic of visceral leishmaniasis control. Am J Trop Med Hyg 55: 125-130.

128. Fernandes AP, Coelho EA, Machado-Coelho GL, Grimaldi G Jr, Gazzinelli RT, et al. (2012) Making an anti-amastigote vaccine for visceral leishmaniasis: rational, update and perspectives. Curr Opin Microbiol 15: 476-485.

129. Borja-Cabrera GP, Correia Pontes NN, da Silva VO, Paraguai de Souza E, Santos WR, et al. (2002) Long lasting protection against canine kala-azar using the FML-QuilA saponin vaccine in an endemic area of Brazil (São Gonçalo do Amarante, RN). Vaccine 20: 3277-3284.

130. Kedzierski L, Zhu Y, Handman E (2006) Leishmania vaccines: progress and problems. Parasitology 133: S87-112.

131. Gradoni L (2001) An update on antileishmanial vaccine candidates and prospects for a canine Leishmania vaccine. Vet Parasitol 100: 87-103.

132. Handman E (2001) Leishmaniasis: current status of vaccine development. Clin Microbiol Rev 14: 229-243.

133. Khamesipour A, Rafati S, Davoudi N, Maboudi F, Modabber F (2006) Leishmaniasis vaccine candidates for development: a global overview. Indian J Med Res 123: 423-438.

134. Abdian N, Gholami E, Zahedifard F, Safaee N, Rafati S (2011) Evaluation of DNA/DNA and prime-boost vaccination using LPG3 against Leishmania major infection in susceptible BALB/c mice and its antigenic properties in human leishmaniasis. Exp Parasitol 127: 627-636.

135. Nagill R, Kaur S (2011) Vaccine candidates for leishmaniasis: a review. Int Immunopharmacol 11: 1464-1488.

136. Araújo MS, de Andrade RA, Sathler-Avelar R, Magalhães CP, Carvalho AT, et al. (2011) Immunological changes in canine peripheral blood leukocytes triggered by immunization with first or second generation vaccines against canine visceral leishmaniasis. Vet Immunol Immunopathol 141: 64-75.

137. Khalil EA, Elhassan AM, Zijlstra EE, Osman OF, Eljack IA, et al. (2000) Safety and immunogenicity of an autoclaved Leishmania major vaccine. East Afr Med J 77: 468-470.

138. Mohebali M, Taran M, Zarei Z (2004) Rapid detection of Leishmania infantum infection in dogs: comparative study using an immunochromatographic dipstick rk39 test and direct agglutination. Vet Parasitol 121: 239-245.

139. Genaro O, de Toledo VP, da Costa CA, Hermeto MV, Afonso LC, et al. (1996) Vaccine for prophylaxis and immunotherapy, Brazil. Clin Dermatol 14: 503-512.

140. Fujiwara RT, Vale AM, França da Silva JC, da Costa RT, Quetz Jda S, et al. (2005) Immunogenicity in dogs of three recombinant antigens (TSA, LeIF and LmSTI1) potential vaccine candidates for canine visceral leishmaniasis. Vet Res 36: 827-838.
141. Moreno J, Nieto J, Masina S, Cañavate C, Cruz I, et al. (2007) Immunization with H1, HASPB1 and MML Leishmania proteins in a vaccine trial against experimental canine leishmaniasis. Vaccine 25: 5290-5300.

142. Molano I, Alonso MG, Mirón C, Redondo E, Requena JM, et al. (2003) A Leishmania infantum multi-component antigenic protein mixed with live BCG confers protection to dogs experimentally infected with L. infantum. Vet Immunol Immunopathol 92: 1-13.

143. de Mendonça LZ, Resende LA, Lanna MF, Aguiar-Soares RD, Roatt BM, et al. (2016) Multicomponent LBSap vaccine displays immunological and parasitological profiles similar to those of Leish-Tec ${ }^{\circledR}$ and Leishmune ${ }^{\star}$ vaccines against visceral leishmaniasis. Parasit Vectors 9: 472.

144. Resende LA, Aguiar-Soares RD, Gama-Ker H, Roatt BM, Mendonça LZ, et al. (2016) Impact of LbSapSal Vaccine in Canine Immunological and Parasitological Features before and after Leishmania chagasi-Challenge. PLoS One 11: e0161169.

145. Roatt BM, Aguiar-Soares RDO, Vitoriano-Souza J, Coura-Vital W, Leôncio Braga S, et al. (2012) Performance of LBSap vaccine after intradermal challenge with L. infantum and saliva of Lu. longipalpis: immunogenicity and parasitological evaluation. PLoS One 7: e49780.

146. Vitoriano-Souza J, Moreira Nd, Menezes-Souza D, Roatt BM, de Oliveira Aguiar-Soares RD, et al. (2013) Dogs immunized with LBSap vaccine displayed high levels of IL-12 and IL-10 cytokines and CCL4, CCL5 and CXCL8 chemokines in the dermis. Mol Immunol 56: 540-548.

147. Fernández L, Carrillo E, Sánchez-Sampedro L, Sánchez C, IbarraMeneses AV, et al. (2018) Antigenicity of eishmania-Activated C-Kinase Antigen (LACK) in Human Peripheral Blood Mononuclear Cells, and Protective Effect of Prime-Boost Vaccination With pCI-neo-LACK Plus Attenuated LACK-Expressing Vaccinia Viruses in Hamsters. Front Immunol 9: 843 .

148. Almeida APMM, Machado LFM, Doro D, Nascimento FC, Damasceno L et al. (2018) New Vaccine Formulations Containing a Modified Version of the Amastigote 2 Antigen and the Non-Virulent. Front Immunol 9: 465.

149. Bhowmick S, Ravindran R, Ali N (2008) gp63 in stable cationic liposomes confers sustained vaccine immunity to susceptible BALB/c mice infected with Leishmania donovani. Infect Immun 76: 1003-1015.

150. Mazumder S, Maji M, Ali N (2011) Potentiating effects of MPL on DSPC bearing cationic liposomes promote recombinant GP63 vaccine efficacy: high immunogenicity and protection. PLoS Negl Trop Dis 5: e1429.

151. Sachdeva R, Banerjea AC, Malla N, Dubey ML (2009) Immunogenicity and efficacy of single antigen Gp63, polytope and polytopeHSP70 DNA vaccines against visceral Leishmaniasis in experimental mouse model. PLoS One 4: e7880.

152. Samant M, Gupta R, Kumari S, Misra P, Khare P, et al. (2009) Immunization with the DNA-encoding N-terminal domain of proteophosphoglycan of Leishmania donovani generates Th1-type immunoprotective response against experimental visceral leishmaniasis. J Immunol 183: 470-479.

153. Guha R, Das S, Ghosh J, Naskar K, Mandala A, et al. (2013) Heterologous priming-boosting with DNA and vaccinia virus expressing kinetoplastid membrane protein-11 induces potent cellular immune response and confers protection against infection with antimony resistant and sensitive strains of Leishmania (Leishmania) donovani. Vaccine 31: 1905-1915.

154. Basu R (2005) Kinetoplastid membrane protein-11 DNA vaccination induces complete protection against both pentavalent antimonialsensitive and -resistant strains of Leishmania donovani that correlates with inducible nitric oxide synthase activity and IL-4 generation: evidence for mixed Th1- and Th2-like responses in visceral leishmaniasis. J Immunol 174: p.7160-7171.

155. da Silva RA, Tavares NM, Costa D, Pitombo M, Barbosa L, et al. (2011) DNA vaccination with KMP11 and Lutzomyia longipalpis salivary protein protects hamsters against visceral leishmaniasis. Acta Trop 120: 185-190.

156. Bhaumik S, Basu R, Sen S, Naskar K, Roy S (2009) KMP-11 DNA immunization significantly protects against L. donovani infection but 
Citation: Fiuza JA, Gaze ST (2018) Immune Response Profile in Susceptibility and Protection in Visceral Leishmaniasis. J Immuno Biol 3: 1000139. doi:10.4172/2476-1966.1000139

Page 10 of 10

requires exogenous IL-12 as an adjuvant for comparable protection against L. major. Vaccine 27: 1306-1316.

157. Li JF, Chen JP, Tian Y, Yang ZW, Ma Y, et al. (2011) [Immunogenicity of the recombinant plasmid of Leishmania donovani amastigote gene]. Zhongguo Ji Sheng Chong Xue Yu Ji Sheng Chong Bing Za Zhi 29: $122-125$.

158. Bhattacharya P, Dey R, Dagur PK, Joshi AB, Ismail N, et al. (2016) Live Attenuated Leishmania donovani Centrin Knock Out Parasites Generate Non-inferior Protective Immune Response in Aged Mice against Visceral Leishmaniasis. PLoS Negl Trop Dis 10: e0004963.

159. Fiuza JA, Santiago Hda C, Selvapandiyan A, Gannavaram S, Ricci ND, et al. (2013) Induction of immunogenicity by live attenuated Leishmania donovani centrin deleted parasites in dogs. Vaccine 31: 1785-1792.

160. Fiuza JA, Gannavaram S, Santiago Hda C, Selvapandiyan A, Souza DM, et al. (2015) Vaccination using live attenuated Leishmania donovani centrin deleted parasites induces protection in dogs against Leishmania infantum. Vaccine 33: 280-288.

161. Selvapandiyan A, Dey R, Nylen S, Duncan R, Sacks D, et al. (2009) Intracellular replication-deficient Leishmania donovani induces long lasting protective immunity against visceral leishmaniasis. J Immunol 183: 1813-1820

162. Fiuza JA, Dey R, Davenport D, Abdeladhim M, Meneses C, et al. (2016) Intradermal Immunization of Leishmania donovani Centrin Knock-Out Parasites in Combination with Salivary Protein LJM19 from Sand Fly Vector Induces a Durable Protective Immune Response in Hamsters. PLoS Negl Trop Dis 10: e0004322.

163. Anand S, Madhubala R (2015) Genetically Engineered Ascorbic aciddeficient Live Mutants of Leishmania donovani induce long lasting Protective Immunity against Visceral Leishmaniasis. Sci Rep 5: 10706.

164. Dey R, Dagur PK, Selvapandiyan A, McCoy JP, Salotra P, et al. (2013) Live attenuated Leishmania donovani p27 gene knockout parasites are nonpathogenic and elicit long-term protective immunity in $\mathrm{BALB} / \mathrm{c}$ mice. J Immunol 190: 2138-2149.

165. Kevin WB, Ron B, Jacquelyn H, Veena V, Stephanie G, et al. (2012) Killed but metabolically active Leishmania infantum as a novel whole-cell vaccine for visceral leishmaniasis. Clin Vaccine Immunol 19: 490-498.

166. Dantas-Torres F (2006) Leishmune vaccine: the newest tool for prevention and control of canine visceral leishmaniosis and its potential as a transmission-blocking vaccine. Vet Parasitol 141: 1-8.
167. Chakravarty J, Kumar S, Trivedi S, Rai VK, Singh A, et al. (2011) A clinical trial to evaluate the safety and immunogenicity of the LEISHF1+MPL-SE vaccine for use in the prevention of visceral leishmaniasis. Vaccine 29: 3531-3537.

168. Coler RN, Goto Y, Bogatzki L, Raman V, Reed SG (2007) Leish-111f, a recombinant polyprotein vaccine that protects against visceral Leishmaniasis by elicitation of CD4+ $\mathrm{T}$ cells. Infect Immun 75: 4648-4654.

169. Stäger S, Smith DF, Kaye PM (2000) Immunization with a recombinant stage-regulated surface protein from Leishmania donovani induces protection against visceral leishmaniasis. J Immunol 165: 7064-7071.

170. Goto Y, Bogatzki LY, Bertholet S, Coler RN, Reed SG (2007) Protective immunization against visceral leishmaniasis using Leishmania sterol 24c-methyltransferase formulated in adjuvant. Vaccine 25: 7450-7458.

171. Mizbani A, Taheri T, Zahedifard F, Taslimi Y, Azizi H, et al. (2009) Recombinant Leishmania tarentolae expressing the $\mathrm{A} 2$ virulence gene as a novel candidate vaccine against visceral leishmaniasis. Vaccine 28: 53-62.

172. Bhowmick S, Ali N (2009) Identification of novel Leishmania donovani antigens that help define correlates of vaccine-mediated protection in visceral leishmaniasis. PLoS One 4: e5820.

173. Carson C, Antoniou M, Ruiz-Argüello MB, Alcami A, Christodoulou V, et al. (2009) A prime/boost DNA/Modified vaccinia virus Ankara vaccine expressing recombinant Leishmania DNA encoding TRYP is safe and immunogenic in outbred dogs, the reservoir of zoonotic visceral leishmaniasis. Vaccine 27: 1080-1086.

174. Sharma A, Madhubala R (2009) Ubiquitin conjugation of open reading frame F DNA vaccine leads to enhanced cell-mediated immune response and induces protection against both antimony-susceptible and -resistant strains of Leishmania donovani. J Immunol 183: 7719-77131.

175. Pirdel L, Hosseini AZ, Rasouli M (2014) Immune response in susceptible $\mathrm{BALB} / \mathrm{c}$ mice immunized with DNA encoding Lipophosphoglycan 3 of Leishmania infantum. Parasite Immunol 36: 700-707.

176. Riede O, Seifert K, Oswald D, Endmann A, Hock C, et al. (2015) Preclinical safety and tolerability of a repeatedly administered human leishmaniasis DNA vaccine. Gene Ther 22: 628-635.

177. Stäger S, Smith DF, Kaye PM (2000) Immunization with a recombinant stage-regulated surface protein from Leishmania donovani induces protection against visceral leishmaniasis. J Immunol 165: 7064-7071. 